\title{
TURNITIN SEBAGAI ALAT DETEKSI PLAGIARISME
}

Anton Risparyanto

Pustakawan Universitas Islam Indonesia

e-mail: anton.risparayanto@yahoo.co.id

\begin{abstract}
Abstrak
Plagiarisme dapat diminimalisir dengan menggunakan software aplikasi Turnitin. Software ini berfungsi untuk mendeteksi persamaan kata dan kalimat yang terdapat pada karya tulis mahasiswa, sehingga kelihatan keaslianya (originil) atau tidak. Masalah ini perlu dilakukan penelitian dengan tujuan untuk mengetahui peran software Turnitin dalam melakukan deteksi plagiarisme karya tulis mahasiswa. Penelitian ini menggunakan metode kuantitatif, dengan jumlah sampel yang diambil sebanyak empat puluh paper tugas akhir mahasiswa. Data dianalisa secara diskritif kuantitatif dan menggunakan uji t sehingga diperoleh kesimpulan (1) Pemahaman plagiarisme terjadi peningkatan setelah karya tulis mahasiswa dilakukan deteksi dengan menggunakan software Turnitin; (2) peran software Turnitin signifikan dalam meminimalisir plagiarisme mahasiswaa dengan nilai $p$-value $=0.000$ lebih kecil dari pada 0.05 (pvalue $=0.000<0.05$ ) dengan kontribusi sebesar $67.8 \%$ karena dipengaruhi oleh faktor persamaan kata atau kalimat yang diambil dari repositori, jurnal online, web dan blog yang beredar di dunia maya.
\end{abstract}

\begin{abstract}
Plagiarism can be minimized by using Turnitin application software. This software is used to detect word equations and sentences contained in student writing, so that the originality is visible or not. This problem needs to be done research with the aim to find out the role of Turnitin software in detecting plagiarism of student papers. This research uses quantitative methods, with forty samples taken as many as forty student final papers. The data were analyzed in a quantitative discrete manner and using the t test in order to conclude (1) The understanding of plagiarism has increased after student papers have been detected by using Turnitin software; (2) the significant role of Turnitin software in minimizing student plagiarism with $p$-value $=0,000$ is smaller than 0.05 ( $p$ value $=0,000<0.05$ ) with a contribution of $67.8 \%$ because it is influenced by the factor of words or sentences taken from repositories, online journals, web and blogs that circulate in cyberspace.
\end{abstract}

Kata kunci:

Turnitin,

deteksi dan plagiarisme

Keywords:

Turnitin, detection and plagiarism

\section{A. PENDAHULUAN}

Kasus plagiarisme sekarang menjadi pembicaraan hangat di lingkungan perguruan tinggi. Hampir semua perguruan tinggi negeri ataupun swasta sedang menggalakan penangan plagiarisme yang merupakan pencurian karya tulis orang lain. Plagiarisme merupakan pengambilan hasil karya tulis orang lain, ide tanpa menyebutkan sumbernya dan diakui sebagai hasil karya miliknya sendiri. Plagiarisme sudah menjadi budaya mahasiswa yang sedang mengerjakan tugas mata kuliah ataupun mereka yang baru mengerjakan tugas khir (skripsi, tesis dan disertasi). Hal ini terjadi karena kurangngya efikasi diri (self-efficacy) dan kepercayaan diri mahasiswa dalam mengerjakan tugas dari dosen, sehingga mereka sengaja mengambil hasil karya tulis milik orang lain dengan tujuan untuk mendapatkan nilai baik (Suryana, 2016). Kejadian plagiarisme juga disebabkan oleh banyaknya tugas dan kurangnya kepercayaan diri yang didorong oleh keinginan mahasiswa untuk mendapatkan nilai baik ((Zalnur, 2012). Kejadian ini juga dipengaruhi berkembangnya teknologi baru dan web pada saat ini (Jereb et al., 2018). Menurut

"Peraturan Menteri Pendidikan Nasional Republik Indonesia Nomor 17 Tahun 2010 Tentang Pencegahan dan Penanggulangan Plagiat di Perguruan Tinggi" Plagiarisme yang sering terjadi di kalangan mahasiswa harus segera dihentikan. Karena plagiarisme setiap hari selalu bertambah dan harus segera dihentikan. Disamping itu plagiarisme juga 
merupakan pelanggaran etika akademik dan dapat menurunkan kompetensi mahasiswa.

Untuk meminimalisir terjadinya plagiarisme di kalangan mahasiswa yang semakin hari terus bertambah, diperlukan suatu software yang dapat melakukan dekteksi persamaan kata dan kalimat secara efektif dan efisien. Salah satu software yang dapat melakukan deteksi secara efektif dan efisien yaitu Turnitin. Software ini telah banyak digunakan oleh berbagai lembaga perpustakaan di perguran tinggi. Upaya perpustakaan menggunakan software Turnitin karena untuk mengurangi terjadinya plagiarisme yang dilakukan oleh mahasiswa. (Aziz et al., 2015). Software Turnitin ini dapat digunakan untuk melacak besarnya persentase (similarity) kesamaan kata dan kalimat dalam suatu karya tulis ilmiah, sehingga dapat memperkecil terjadinya plagiarisme di kalangan mahasiswa.

Mengurangi terjadinya plagiarisme sudah menjadi kewajiban setiap lembaga pendidikan terutama perguruan tinggi. Karena plagiarisme merupakan pencurian hasil karya tulis orang lain yang dapat menurunkan integritas akademik. Setiap lembaga harus dapat mengambil tindakan tegas dalam mengurangi dan memberantas terjadinya plagiarisme. Lembaga universitas dapat mengambil tindakan tegas terhadap mahasiswa yang sering melanggar plagiarisme (Mohtar et al., 2018). Pengurangan terjadinya plagiarissme dapat terlaksana dengan baik apabila pihak istansi mengambil langkah tegas dengan memberi sangsi terhadap mahasiswa yang melakukan pelanggaran dengan sengaja. Sebab apabila tidak dilakukan tindakan pemberian sanksi secara tegas mahasiswa akan mengulang plagiarisme lagi.

Software Turnitin mempunyai peran yang sangat besar dalam mengurangi tarjadinya plagiarisme di kalangan mahasiswa. Software Turnitin (Turnitin systems: a deterrent) merupakan salah satu alat deteksi yang dapat meminimalisir terjadinya plagiarisme di kalangan mahasiswa (Hecker, 2012).
Aplikasi software ini dapat melakukan deteksi karya tulis secara global tidak mengenal waktu, bahasa dan tempat. Setiap mahasiswa yang melakukan plagiarisme terhadap karya milik orang lain maka akan dapat di lacak dan dideteksi dengan menggunakan software Turnitn, sehingga dapat diketahui keaslian (originil) dan besarnya persentase (similarity) plagiarisme karya tulis. Semakin baik prosedur pelaksanaan deteksi plagiarisme yang dilakukan oleh suatu lembaga maka peran softaware Turnitin akan melakukan deteksi plagiarisme dengan baik. Kebijakan lembaga/institusi dalam penyusunan prosedur sangat menentukan keberhasilan dalam menangani pelanggaran plagiarisme yang terjadi di kalangan mahasiswa (Carnero et al., 2017)yet widespread type of research misconduct, and is often neglected in developing countries. Despite its far-reaching implications, plagiarism is poorly acknowledged and discussed in the academic setting, and insufficient evidence exists in Latin America and developing countries to inform the development of preventive strategies. In this context, we present a longitudinal case study of seven instances of plagiarism and cheating arising in four consecutive classes (2011-2014. Berhasilnya software Turnitin dalam melakukan deteksi plagiarisme juga sangat ditentukan, seberapa jauh kemampuan petugas dalam mengoperasikan software aplikasi yang digunakan sebagai pendeteksi plagiarisme. Merujuk uraian di atas dapat dinyatakan bahwa software Turnitin mempunyai peran yang sangat baik dalam penangan plagiarisme yang di kalangan mahasiswa, sehingga banyak institusi menggunakannya.

Masalah peran software Turnitin signifikan dalam melakukan deteksi terjadinya plagiarisme di kalangan mahasiswa perlu dilakukan penelitian dengan rumusan masalah sebagai berikut: (1) Bagaimana pengertian dan pemahaman plagiarisme mahasiswa sebelum dan sesudah karya tulis mereka dilakukan pengecekan dengan menggu- 
nakan software Turnitin; (2) apakah software Turnitin berperan signifikan dalam meminimalisir terjadinya plagiarisme; (3) berapa kontribusi dan faktor-faktor apakah yang mempengaruhi software Turnitin dalam pengurangan dan pencegahan plagiarisme?. Penelitian ini bertujuan untuk mengetahui pemahaman plagiarisme mahasiswa sebelum dan sesudah karya tulis mereka dilakukan deteksi dengan menggunakan software Turnitine; peran software Tunitin dalam mengurangi tingkat, kontribusinya dan faktor-faktor yang mempengaruhinya. Adapun manfaatnya dapat digunakan sebagai dasar pengembangan konsep kebijakan Universitas dalam pencegahan dan pengurangan terjadinya plagiarisme di lembaga yang terkait.

\section{B. TINJAUAN TEORITIS}

\section{Definisi Plagiarisme}

Plagiarisme didefinisikan sebagai pengambilan kata, ide, data atau kalimat orang lain tanpa menyebutkan sumbernya, begitu juga menggunakan blog milik orang lain untuk mengerjakan tugas sendiri dan menganggapnya sebagai milik sendiri (Spiteri et al., 2007). Plagiarisme juga berarti mengambil karya orang lain (kekayaan intelektual) untuk dimasukkan ke dalam pekerjaannya sebagai hasil ciptanya tanpa menyebutkan sumber aslinya sebagai rujukan. Plagiarisme juga merupakan pengambilan kata, ide, atau data orang lain yang diakui sebagai miliknya sendiri (Spiteri et al., 2007).

\section{Jenis dan Karateristik Plagiarisme}

Menurut "Peraturan Menteri Pendidikan Nasional Indonesia No. 17 Tahun 2010 Tentang Pencegahan Dan Penanggulangan Plagiat Perguruan Tinggi" BAB II Pasal 2 ayat (1) menyatakan bahwa jenis kegiatan yang termasuk dalam plagiarisme diantaranya: melakukan kutipan (sitasi) dan merumuskan berbagai kata-kata, kalimat, informasi, data, memanfaatkan sumber pendapat, gagasan, teori dan pandangan orang lain tanpa menyebutkan sumber menyebutkan sumber secara memadai.
Namun demikian plagiarisme juga dapat dikelompokkan menjadi menjadi 4 jenis yaitu: plagiarisme apropriasi, plagiarisme penelitian (research), plagiarisme gagasan (ide) dan plagiarisme sendiri (self plagiarisme) (Lewis, 2007).

\section{a. Plagiarisme Apropriasi}

Sering kali mahasiswa melakukan penjiplakan karya orang lain secara terangterangan tanpa menyebutkan sumbernya. Bahkan tanpa memperhatikan asal sumber informasi yang diambil dan adanya anggapan pada dirinya tidak mengetahui terhadap peraturan plagiarisme dalam pengambilan sumber yang digunakan sebagai sitasi. Secara terang terangan melakukan plagiarisme walapun sudah adanya peraturan pelanggaran etika akademik. Bahkan sumber yang tidak dapat dipertanggung jawabkan pun mereka gunakan sebagai pelengkap tugas. Plagiarisme apropriasi merupakan pengambilan hasil karya orang lain secara terang-terangan tanpa memperhatikan siapa pemiliknya secara keseluruhan tanpa merubah kata atau kalimat sedikitpun masih dalam bentuk aslinya yang diakui sebagai karya sendiri. Adapun ciri-ciri umum plagiarime apriori yaitu adanya pengambilan kalimat dengan cara kopi dan paste pada hasil karya milik orang lain.

\section{b. Plagiarisme Penelitian}

Plagiarisme penelitian, plagiat ini dengan cara memadukan kata-kata /kalimat orang lain dengan yang dipadukan dengan milik sendiri melalui suatu parafrase. Disamping itu juga tidak mencantumkan sumbernya. Ciri plagiarisme jenis ini dilakukan dengan mengambil beberapa kalimat orang lain sebagai kata kunci (key word) kemudian diuraikan dengan menggunakan sendiri dengan tanpa mencantumkan asal sumbernya.

\section{c. Plagiarisme Mandiri}

Plagiarisme mandiri (self plagiarisme), merupakan pengambilan kembali sebagain hasil 
karya sendiri yang sudah lama untuk dipublikan ulang sebagai karya terbaru. Plagiarism mandiri ini sering terjadi pada penulis yang melakukan sitasi milik sendiri tanpa melalui perubahan terhadaap jenis informasi yang akan dipublikasikan. Plagiarsme mandiri ini termasuk melanggar etika karya akademik, karena informasi yang disampaikan sudah tidak mutakhir lagi, karena informasi yang dibutuhkan oleh pembaca merupakan perkembangan informasi yang terbaru.

\section{d. Plagiarisme Ide}

Plagiarisme gagasan (ide), yaitu pengambilan ide orang lain yang diakui sebagai milik sendiri. Plagiarsme jenis ini sangat terselubung karena pengambilan ide milik orang lain sulit untuk diketahui dan diakui sebagi miliknya sendiri.

\section{Software Turnitin}

Turnitin merupakan salah satu software pendeteksi plagiarisme yang dikembangkan oleh Universitas California Berkeley melalui perusahaan Ipardigms. Turnitine ini berfungsi untuk mengecek tingkat kesamaan kalimat, kata, paragraf, struktur kata suatu karya tulis dengan karya tulis yang dibuat seseroang atau mahasiswa dengan milik ornag lain yang dipublikasikan sebelumnya. Berdasarkan kesamaan tersebut akan ditampilkan jumlah persentasenya (similarity). Dalam melakukan deteksi keaslian (original) karya tulis, software ini menerapkan sistem cloud yang berbasis global. Turnitin telah digunakan oleh 126 negara dari yang terdiri dari kurang lebih 10.000 lembaga . Turnitin juga didukung oleh Warburg Pincus dan berkantor pusat di Oakland, California, dengan kantor internasional di Newcastle (https://www.d2l.com/partners/ directory/turnitin-iparadigms).

Sistem kerja aplikasi software Turnitin dengan menggunakan basis web yang dapat dijalankan dengan menggunakan akun yang diperoleh dengan sistem sewa. Dalam menjalan software ini pengguna cukup melakukan browsing kemudian akan diminta memasukan user name dan pasword (www. turnitin.com.). Software Turnitin akan menampilkan beberapa menu yang sebagai petunjuk penggunaannya. Dari beberapa menu tersebut pengguna diarahkan untuk melakukan submit dokumen yang melalui salah satu menu sebagai langkah awal dalam melakukan pendeteksian secara global. Hasil deteksi akan ditampilkan besarnya persentase (similarity) plagiarisme suatu karya tulis apabila dibandingkan dengan artikel yang termuat pada berbagai jurnal online, repository dan tulisan yang dimuat dalam web.

\section{METODE PENELITIAN}

Metode yang digunakan dalam penelitian ini yaitu kuantitatif. Pengambilan sampel dilakukan terhadap 40 paper tugas akhir karya ilmiah mahasiswa secara berpasangan. Sampel diambil menggunakan metode probability sampling dengan menggunakan kuesioner yang terdiri dari beberapa item pertanyaan sebagai alat ukur. Sebagai variabel yaitu software Turnitin sebagai variabel bebas alat deteksi dan plagiarisme berfungsi sebagai variabel terikat. Variabel tersebut dijabarkan menjadi dua dimensi kejujuran dan pemahaman mahasiswa terhadap plagiarisme. Penelitian dilakukan di Direktorat Perpustakaan Universitas Islam Indonesia sebagai tempat similarity plagiarisme. Data dianalisa dengan menggunakan uji $t$ dan regresi linier sederhana yang dibantu program SPSS. Persmaan matematis uji regresi linier yang digunakan dalam analisa data tersebut yaitu $Y=\beta 0+\beta_{1} X_{1}+e t$ dengan keterangan :

$$
\begin{aligned}
& \beta_{0^{\prime}} \beta_{1^{\prime}}=\text { Koefisien } \\
& Y=\text { Plagiarisme (variabel dependent) } \\
& X_{1}=\text { Turnitne (variabel independent) } \\
& e=\text { Error Term }
\end{aligned}
$$

Uji hipoteis $\mathrm{t}$ digunakan untuk menguji nilai signifikan dengan ketentuan, apabila nilai probalitas t hitung $p$-value kurang dari pada 0.05 atau ( $p$-value $<0.05$ ) maka dinyatakan signifikan, tetapi sebaliknya apabila t hitung $p$-value lebih besar dari pada 0.05 
atau ( $p$-value $>0.05$ ) dinyatakan tidak signifikan. Uji korelasi digunakan untuk mengetahui besarnya kontribusi pengaruh varisbel bebas terhadap variabel terikat dengan menggunakan persamaan matematis: $\boldsymbol{R}^{2}=\frac{\sum\left(\dot{\mathrm{Y}}_{i}-\mathrm{Y}\right)^{2}}{\sum\left(\mathrm{Y}_{i}-\mathrm{Y}\right)^{2}}=\frac{E S S}{T S S}=\frac{\sum \dot{y}^{2}}{\sum \dot{y}^{2}}=\frac{\beta_{1}^{2} \sum x_{i}^{2}}{\sum y_{i}^{2}}=\beta_{1}^{2}\left(\frac{\sum x_{i}^{2}}{\sum y_{i}^{2}}\right)$

Dengan keterangan sebagai berikut $\mathrm{R}=$ besarnya hubungan

$$
\begin{aligned}
& X=\text { Variabel bebas } \\
& Y=\text { Variabel terikat (prediktor) }
\end{aligned}
$$

\section{HASIL DAN PEMBAHASAN}

Hasil penelitian masalah software Turnitin yang digunakan sebagai alat pendeteksi plagiarisme ini akan dijelaskan secara diskritif kuantitatif mengenai pengertian dan pemahaman plagiarisme mahasiswa sebelum dan sesudah dilakukan pengecekan karya tulis mereka dengan menggunakan software Turnitin. Software tersebut mempunyai peran yang sangat penting dalam pengurangan dan penanggulangan plagiarisme yang terjadi di kalangan mahasiswa. Besarnya peran tersebut dapat diketahui dari berbagai faktor yang berkontribusi dalam mengurangi terjadinya plagiarisme mahasiswa.

\section{Pengetahuan Plagiarisme Sebelum Deteksi Plagiarisme.}

Pengertian dan pemahaman plagiarisme mahasiswa sebelum melakukan deteksi dengan karya tulisnya dengan menggunakan software Turnitin sangat beragam. Mereka ada yang sudah paham tetapi juga masih banyak yang belum paham terhadap plagiarisme. Berdasarkan hasil penelusuran yang dilakukan dengan menggunakan kuesioner terhadap 40 paper yang dijadikan sebagai responden sebelum melakukan deteksi dengan menggunakan software Turnitin. Diperoleh hasil seperti tampak pada tabel 1, bahwa 55\% mahasiswa kurang memahami plagiarisme, sedang yang sudah paham hanya $45 \%$ saja. Artinya mahasiswa yang sudah paham plagiarisme lebih kecil apabila dibandingakan dengan yang belum paham sebelum dilakukan cek plagiarisme. Mahasiswa yang belum paham tersebut terdiri dari $30 \%$ sangat kurang paham dan 25\% kurang paham. Sisanya 45\% persen mahasiswa paham plagiarisme terdiri dari $20 \%$ mempunyai pemahaman yang baik dan $25 \%$ pemahamannya sangat baik. Hal ini menunjukkan bahwa sebelum dilakukan cek plagiarisme mahasiswa masih kurang paham plagiarisme.

Tabel 1

\begin{tabular}{|l|c|c|}
\hline \multicolumn{1}{|c|}{ Keterangan } & Jumlah & Persentase (\%) \\
\hline Sangat kurang & 12 & 30 \\
\hline Kurang & 10 & 25 \\
\hline Baik & 8 & 20 \\
\hline Sangat baik & 10 & 25 \\
\hline Jumlah & 40 & 100 \\
\hline
\end{tabular}

Mereka belum mengetahui bahwa cek plagiarisme dengan menggunakan software Turnitin bersifat global sehingga dapat membandingkan persamaan kata ataupun kalimat yang diambil dari berbagai sumber dan bahasa yang beredar di dunia maya.

\section{Pengetahuan Plagiarisme Sesudah Deteksi Plagiarisme}

Pengetahuan plagiarisme mahasiswa dalam membuat karya tulis ilmiah mengalami peningkatan setelah dilakukan pengecekan dengan menggunakan software Turninitn. Mereka sudah mengetahui bahwa software Turnitin dapat mendeteksi persamaan kata dan kalimat apabila mengambil hasil karya orang lain tanpa melakukan parafrase kalimat. Besarnya peningkatan pemahaman plagiarisme tersebut seperti tampak pada tabel 2 yaitu menjadi $62.5 \%$ setelah dilakukan pengecekan dengan menggunakan software Turnitin. Hal ini terdiri dari $32.5 \%$ menunjukkan baik dan $30 \%$ sangat baik. Sedangkan kurangnya pemahaman plagirisme turun menjadi $37.5 \%$ yang terdiri dari $20 \%$ sangat kurang dan $17.5 \%$ kurang baik. Terjadinya peningkatan pemahaman plagiarisme mahasiswa tersebut setelah mereka melakukan deteksi karya tulisnya dengan menggunakan software Turnitin. 
Tabel 2

\begin{tabular}{|l|c|c|}
\hline \multicolumn{1}{|c|}{ Keterangan } & Jumlah & Persentase (\%) \\
\hline Sangat kurang & 8 & 20 \\
\hline Kurang & 7 & 17.5 \\
\hline Baik & 13 & 32.5 \\
\hline Sangat baik & 12 & 30 \\
\hline Jumlah & 40 & 100 \\
\hline
\end{tabular}

Pengecekakan plagiarisme dengan menggunakan softwre Turnitin dengan tujuan agar mahasiswa tidak melakukan pagiarisme apabila dalam membuat karya tulis, sehingga mereka selalu melakukan parafrase kalimat dan mencantumkan sumbernya.

\section{Peran Software Turnitin Dalam Melacak Plagiarisme}

Sekarang ini kejadian plagiarisme di kalangan mahasiswa semakin hari bertambah marak bahkan sudah menjadi budaya mahasiswa. Plagiarisme merupakan perbuatan pengambilan karya tulis sengacara sengaja yang akan digunakan untuk untuk memperoleh angka kredit melalui suatu pengutipan milik orang lain dengan tanpa menyebutkan sumbernya dan diakui sebagai hasil karyanya (Suryana, E. 2016). Software Turnitin merupakan salah satu yang dapat melakukan deteksi plagiarisme melalui persamaan kata dan kalimat secara akurat dan efesien. Software Turnitin mempunyai kinerja yang sangat baik yang dilengkapi dengan berbagai menu fitur terlengkap dalam melakukan deteksi plagiarisme apabila dibandingkan dengan yang lain (Afdhal; Taufan Chalis; Tauiq A. Gani, 2014). Software ini dapat melakukan pendeteksian persamaan kata dan kalimaat agar dapat meminimalisir terjadinya plagiarisme sekecil mungkin. Karena plagiarisme merupakan pencurian hasil karya tulis ilmiah orang lain yang harus segera dihentikan.

Plagiarisme bukan hanya pengambilan kata atau kalimat dan ide saja, tetapi juga menyangkut struktur kata, paragraf, penggalan kata, pemberian tanda baca seperti pemberian tanda titik koma. Apabila dua bacaan paper disandingkan dan terjadi persamaan maka dikatakan plagiarisme. Plagiarisme juga merupakan pengambilan hasil karya orang lain yang tidak mencantumkan sumbernya. Karya tersebut bisa berupa gambar, grafik, batik, lagu, kata, kalimat, struktur paragraf yang tidak mencantumkan sumbernya. Disamping itu plagiarisme juga dapat dilakukan secara keseluruahan kalimat ataupun sebagaian kata. Kejadian plagiarisme sudah menjadi kebiasaan di kalangan mahasiswa, sehingga harus segera diminimalisir dan dihentikan karena melanggar etika akademis.

Untuk menghentikan kejadian plagiarisme secara efektif dan efisien diperlukan software aplikasi yang dapat mendeteksi secara akurat dan sistimatis. Salah satunya yaitu software Turnitin yang dapat melakukan deteksi kesamaan kata dan kalimat hasil karya ilmiah mahasiswa. Software ini bekerja dengan membandingkan persamaan kata atau kalimat yang karya ilmiah yang dibuat oleh mahasiswa dengan milik orang lain yang terdapat dalam suatu web, blog, junal online yang sudah disubmit ke dunia maya dengan melalui jaringan internet. Apabila terdapat kesamaan kata atau kalimat, maka hasil karya tersebut dapat terdeteksi dan hasilnya dapat ditunjukkan dengan besarnya persentase (similarity) setelah dibandingkan dengan berbagai sumber yang berada pada suatu web tertentu. Suatu karya ilmiah dikatakan plagiarisme apabila terjadi persamaan kata atau kalimat dari karya yang dimuat dalam suatu web.

Software Turnitin mempunyai peran yang signifikan dalam melakukan pendeteksian plagiarisme. Artinya apabila pendeteksian suatu karya dilakukan secara baik maka plagiarisme yang dilakukan mahasiswa dalam membuat suatu karya tulis akan dapat dilacak secara efisien. Tetapi apabila prosedur pelaksanaan pendeteksian plagiarisme kurang baik maka tingkat palgiarisme mahasiswa dalam membuat karya tulis ilmiah akan tinggi. Karena akuratisasi dalam pelacakan plagiarisme juga tergantung dari prosedur pengecekan yang 
dibuat oleh institusi terkait. Artinya keberhasilan pendekteksian plagiariasme yang dilakukan dengan menggunakan software Turnitin juga tidak bisa lepas dari kebijakan yang terdapat pada institusi setempat.

Data menunujukan bahwa apabila pendeteksian terhadap hasil karya ilmiah mahasiswa dilakukan dengan prosedur yang baik mempunyai peran yang signifikan terhadap tingkat plagiarisme mahasiswa. Hal ini seperti tampak pada tabel 3 Coefficients ${ }^{a}$ terlihat bahwa besarnya probabilitas nilai t hitung sebesar 0.000 lebih kecil dari pada 0.05 ( $p$-value $=0.000<0.05$ ). Hasil ini mempunyai makna bahwa peran software Turnitin signifikan dalam mengurangi terjadinya deteksi plagiarisme. Artinya apabila pendeteksian persamaan kata dan kalimat menggunakan software Turnitin dilakukan dengan baik maka plagiarisme akan dapat ditekan seminim mungkin. Tetapi sebaliknya apabila prosedur pendeteksian kurang baik maka hasilnya kurang maksimal. Karena keberhasilan software Turnitin melakukan pendeteksian persamaan kata dan kalimat juga berdasarkan prosedur yang terdapat pada istansi setempat. Hasil ini sejalan dengan peneliti sebelumnya yang menyatakan pemanfaatan softawre Turnitin sangat berperan dalam melakukan pelacakan dan mengindikasi terjadinya plagiarisme karya tulis ilmiah mahasiswa (Sinaga, 2018).

\begin{tabular}{|c|c|c|c|c|c|c|}
\hline & & Tabel 3 & ofttc & its $\mathbf{a}^{\mathbf{a}}$ & & \\
\hline & Model & $\begin{array}{l}\text { Unstanda } \\
\text { Coeffic }\end{array}$ & $\begin{array}{l}\text { rdized } \\
\text { ents }\end{array}$ & $\begin{array}{c}\text { Standardized } \\
\text { Coefficients }\end{array}$ & $t$ & Siq. \\
\hline & & Std. Error & Beta & & & \\
\hline & (Constant) & 12,593 & 8,618 & & 1,461 & , 154 \\
\hline & Plagiarsime & ,745 & ,094 & 823 & 7,950 & ,000 \\
\hline
\end{tabular}

Dependent Variable: Turnitin

Apabila kejadian plagiarisme di kalangan mahasiswa dalam membuat karya tulis ilmiah dapat diminimalisir dengan baik maka akan dapat citra akademik akan meningkatkan sehingga menunjukkan adanya sifat kejujuran mahasiswa dalam membuatak karya tulis ilmiah. Hal ini terjadi mahasiswa karena tidak melakukan plagiarisme lagi dan mahasiswa sudah dapat meninggalkanya plagiarisme. Disamping itu juga menunjukkan adanya peningkatan kompetensi mahasiswa dalam membuat karya tulis. Hal ini sejalan dengan penelitian sebelumnya bahwa lembaga yang menggunakan aplikasi software Turnitin dapat mengurangi dan menghindari plagiarisme di kalangan mahasiswa yang sedang membuat karya tulis ilmiah (Andayani, 2017). Berdasarkan pembahasan diatas dapat disimpulkan bahwa software Turnitin mempunyai peran signifikan dalam meminimalisir terjadinya plagiarisme.

\section{Kontribusi dan Faktor-Faktor Yang Mempengaruhi Software Turnitin}

Tunitin merupakan software sistem sewa berbayar yang dikembangkan oleh Universitas California, Berkeley dan diproduksi oleh perusahaan Ipardigms. Sofwatre aplikasi ini sudah digunakan di Universitas Negeri ataupun Swasta dari berbagai negara yang didukung oleh beberapa jenis bahasa sesuai dengan kebutuhanya. Software ini dapat melakukan pendeteksian persamaan kata dan kalimat yang berasal dari berbagai sumber informasi seperti repository, jurnal online, blog dan tulisan lain yang beredar secara global melalui jaringan internet di seluruh dunia. Software Turnitin mempunyai kontribusi yang signifikan terhadap pengurangan dan pencegahan plagiarisme karya tulis mahasiswa. Besarnya kontribusi software Turnitin dalam mengurangi dan mencegah terjadinya plagiarisme seperti tampak pada Tabel 4 Model Summary ${ }^{b}$ dengan nilai R Square 0.678 atau sebesar $67.8 \%$. Sisanya sebesar $32.2 \%$ merupakan faktor lain yang terdapat diluar penelitian. Hasil ini menunjukkan bahwa software Turnitin mempunyai kontribusi besar dalam mengurangi terjadinya plagiarisme di kalangan mahasiswa dalam membuat karya tulis. Karena software Turnitin dapat mendeteksi kesamaan konten yang terdapat dalam suatu web sehingga mempunyai manfaat signifikan dalam 
mengindentifikasi kasus plagiarisme (Jones, 2008). Ada beberapa faktor yang menyebabkan kontribusi software Turnitin sebesar $67.8 \%$ dalam mendekteksi plagiarisme karya tulis mahasiswa. Beberapa faktor yang menjadikan software Turnitin dapat mendeteksi plagiarisme mahasiswa dengan baik yaitu: (1) repository perguruan tinggi dari berbagai negara dan bahasa yang dipublikasikan secara global melalui internet. Repository ini memuat berbagai hasil karya tugas akhir mahasiswa (skripsi, tesis dan disertasi) yang didukung dengan berberbagai data yang valid dan disajikan menggunakan struktur tata bahasa sesuai ejaannya ; (2) jurnal online yang dipublikasikan oleh berbagai penerbit; (3) blog dan web yang mempublikasikan berbagai karya tulis, dari berbagai faktor tersebut sehingga dapat mendeteksi terjadinya plagiarisme karya tulis yang dihasilkan oleh mahasiswa.

\section{Tabel 4Model Summaryb}

\begin{tabular}{|c|c|c|c|c|}
\hline Model & $\bar{R}$ & R Square & Adjusted R Square & $\begin{array}{c}\text { Std. Error of the } \\
\text { Estimate }\end{array}$ \\
\hline 1 &, 823 & ,678 & ,667| - - - & 2,7208 \\
\hline
\end{tabular}

b. Dependent Variable: Turnitin

Berdasarkan hasil uji regresi linier sederhana peran software Turnitin dalam mengurangi dan mencegah terjadinya plagiarisme diperoleh persamaan matematis $\mathrm{Y}=0.745 \mathrm{X}+12.593$ seperti tampak pada tabel tabel 4 Coefficients ${ }^{\mathbf{a}}$. Persamaan ini mempunyai makna bahwa 12.593 merupakan konstata signifikan, sedangkan 0.745 merupakan koefisien softaware Turnitin yang mempunyai makna bahwa apabila terjadi peningkatan satu kali maka plagiarisme akan mengalami kenaikan sebesar 0.745. Hasil ini menunjukkan bahwa keberhasilan dalam mengurangi dan mencegah terjadinya plagiarisme sangat ditentukan oleh peran software Turnitin. Apabila mahasiswa melakukan plagiarisme terhadap karya tulis sebelumnya maka akan terdeteksi, karena setiap istansi pendidikan selalu melakukan pengecekan dengan menggunakan software aplikasi plagiarisme seperti Turnitin ataupun yang lainya.
Disamping berperan siginifikan dalam meminimalisir terjadinya plegiarisme, software Turnitin juga mempunyai konstribusi besar dalam menanggulangi terjadinya plagiarisme di kalangan mahasiswa. Besarnya kontribusi software Turnitine terhadap pencegahan plagiarimse tersebut seperti ditunjukkan pada tabel 2 sebesar $67.8 \%$ yang sisanya $32.2 \%$ dipengaruhi oleh faktor-faktor lain di luar penelitian. Hal ini terjadi karena software Turnitin masih mempunyai beberapa kekurangan belum dapat mendetksi file dalam format gambar (jipeg), tulisan yang bertipo dan dimanipulasi dengan mengubah warna sama dengan kertasnya (Manunggal \& Christiani, 2018). Berdasarkan pembahasan di atas dapat disimpulkan software Turnitin mempunyai kontribusi besar dalam mengurangi dan mencegah terjadinya plagiarisme. Karena software Turnitin berhasil membandingkan parsamaan kata dan kalimat hasil karya tulis mahasiswa dengan lainya yang terdapat pada dunia maya seperti dari repository, jurnal online, blog dan web, sehingga dapat diketahui prosentase plagiarismenya.

\section{E. PENUTUP}

Setelah dilakukan pembahasan secara panjang maka dapat disimpulkan bahwa Turnitin merupakan salah satu software aplikasi pendeteksi plagiarisme sangat berarti di kalangan akademik. Software ini dapat melakukan deteksi plagiarisme karya tulis mahasiswa seara efektif dan efisien. Mahasiswa mengalami peningkatan pemahaman plagiarisme setelah mereka melakukan cek plagiarisme dengan menggunakan software Turnitin. Hasil ini menunjukkan bahwa software turnin mempunyai peran signifikan dalam meningkatkan pemahaman plagiarisme mahasiswa. Hal ini disebabkan software Turnitin dapat membandingkan persamaan kata dan kalimat hasil karya tulis mahasiswa dengan hasil karya milik orang lain yang terdapat pada repository, jurnal online, web dan blog. 
Berdasarkan kesimpulan di atas peneliti memberikan rekomendasi kepada berbagai pihak yang terkait dalam meminimalisir terjadinya persamaan kata dan kalimat karya tulis mahasiswa sebaiknya dilakukan cek plagiarisme dengan menggunakan software Turnitin. Karena software tersebut mempunyai peran yang signifikan dalam mengurangi terjadinya plagiarisme.

\section{Daftar Pustaka}

Afdhal; Taufan Chalis; Tauiq A. Gani. (2014). Analisa Perbandingan Aplikasi Pendeteksi Plagiat Terhadap Karya Ilmiah. Seminar Nasional Dan Expo Teknik Elektro, May, 193-199. Diakses pada tanggal 2-1-2020 dari https://www.researchgate.net

Andayani, U. (2017). Penggunaan Software Turnitiln Untuk Mendeteksi Tindakan Plagiarisme. Penggunaan Software Turn It In Untuk Mendeteksi Tindakan Plagiarisme, 16(1), 33-40. Diakses pada tanggal 3-1-2020 dari journal.uinjkt.ac.id

Aziz, L. A., Irhandayaningsih, A., \& Kurniawan, A. T. (2015). Upaya Perpustakaan dalam Mengurangi Plagiarisme Pada Karya IImiah Mahasiswa (Studi Kasus di UPT Perpustakaan UNIKA Soegijapranata). Jurnal Ilmu Perpustakaan, 4(3), 1-13. Diakses pada tanggal 12-1-2020 dari https://ejournal3. undip.ac.id

Carnero, A. M., Mayta-Tristan, P., Konda, K. A., Mezones-Holguin, E., Bernabe-Ortiz, A., Alvarado, G. F., Canelo-Aybar, C., Maguiña, J. L., Segura, E. R., Quispe, A. M., Smith, E. S., Bayer, A. M., \& Lescano, A. G. (2017). Plagiarism, Cheating and Research Integrity: Case Studies from a Masters Program in Peru. Science and Engineering Ethics, 23(4), 1183-1197. https://doi. org/10.1007/s11948-016-9820-z
Hecker, N. C. (2012). Mitigating Plagiarism In Large Introductory Courses In Higher Education [The University of Alabama]. Diakses pada tanggal 5-1-2020 dari ir.ua. edu

Https://www.d2l.com/partners/directory/ turnitin-iparadigms. Diakses pada tanggal 22-1-2020

Https://www.turnitin.com. Diakses pada tanggal 21-1-2020 dari

Jereb, E., Perc, M., Lämmlein, B., Jerebic, J., Urh, M., Podbregar, I., \& Šprajc, P. (2018). Factors influencing plagiarism in higher education: A comparison of German and slovene students. PLOS ONE, 13(8), 1-16. https://doi.org/10.1371

Jones, K. O. (2008). Practical Issues for Academics Using the Turnitin Plagiarism Detection Software. Proceedings of the 9th International Conference on Computer Systems and Technologies and Workshop forPhDStudents in Computing, CompSysTech'08, March. https://doi.org/10.1145/1500879.1500935

Lewis, N. P. (2007). Paradigm Disguise: Systemic Influences On Newspaper Plagiarism [University of Maryland]. In Dissertation. Diakses pada tanggal 2-11-2019 dari https://drum.lib.umd.edu

Manunggal, Y. C., \& Christiani, L. (2018). Pemanfaatan Sistem Deteksi Plagiarisme Menggunakan Turnitin ${ }^{\circledR}$ Pada Jurnal Mahasiswa Universitas Dian Nuswantoro. Jurnal Ilmu Perpustakaan, 7(2), 231-240. Diakses pada tanggal 4-1-2020 dari https:// ejournal3.undip.ac.id.

Mohtar, W. H. M. W., Aima, A. . A., Abdullah, N. A., Yusoff, N. I. M., \& Mutalib, A. A. (2018). Kesedaran dan Kelakuan Pelajar Prasiswazah Terhadap Aktiviti Plagiat dalam Penulisan Akademik. AJTLHE, 10(1), 1-23. Diakses pada tanggal 24-3-2020 dari 
ejournals.ukm.my/ajtlhe

Peraturan Menteri Pendidikan Nasional Indonesia

No. 17 tahun 2010 tentang Pencegahan dan Penanggulangan Plagiat Perguruan Tinggi httprepository.ung.ac.id.pdf (pp. 1-9). (2010). Diakses pada tanggal 18-1-2020 dari http://repository.ung.ac.id.pdf

Sinaga, S.Y. (2018). Penggunaan Aplikasi Turnitin Sebagai Sarana Cek Plagiarisme dalam Layanan Perpustakaan Universitas Ukrida. BIBLIOTIKA: Jurnal Kajian Perpustakaan Dan Informasi, 2(2), 123-131. https://doi. org/10.17977/um008v2i22018p123

Spiteri, D., Grima, G., PaulBartolo, P., Galea, S., Gatt, S., Gatt, I., \& Portelli, T. (2007). How to avoid plagiarism. University of Malta. Diakses pada tanggal 2-3-2020 dari www. um.edu.mt

Suryana, E. (2016). Self Efficacy Dan Plagiarisme Di derguruan Tinggi. Tadrib: Jurnal Pendidikan Agama Islam, 2(2), 214-237. Diakses pada tanggal 12-3-2020 dari jurnal.radenfatah.ac.id

Zalnur, M. (2012). Plagiarisme Di Kalangan Mahasiswa Dalam Membuat Tugas-Tugas Perkuliahan Pada Fakultas Tarbiyah lain Imam Bonjol Padang. AL-Ta Lim, 19, 55. https://doi.org/10.15548/jt.v19i1.6 
